This item was submitted to Loughborough's Research Repository by the author.

Items in Figshare are protected by copyright, with all rights reserved, unless otherwise indicated.

\title{
Contractor practices for managing extended supply chain tiers
}

PLEASE CITE THE PUBLISHED VERSION

http://dx.doi.org/10.1108/SCM-04-2013-0142

PUBLISHER

(C) Emerald

VERSION

AM (Accepted Manuscript)

LICENCE

CC BY-NC-ND 4.0

REPOSITORY RECORD

Pala, Mesut, Francis Tekyi Edum-Fotwe, Kirti Ruikar, Nathan Doughty, and Chris Peters. 2019. "Contractor Practices for Managing Extended Supply Chain Tiers". figshare. https://hdl.handle.net/2134/15273. 


\title{
Contractor practices for managing extended supply chain tiers
}

\author{
Mesut Pala \\ Centre for Innovative and Collaborative Engineering, Loughborough University, UK; m.pala@lboro.ac.uk \\ Francis Edum-Fotwe \\ School of Civil and Building Engineering, Loughborough University, UK; f.t. F.T.Edum-fotwe@lboro.ac.uk \\ Kirti Ruikar \\ School of Civil and Building Engineering, Loughborough University, UK; k.d.ruikar@lboro.ac.uk \\ Nathan Doughty \\ Asite Solutions Ltd, London; Nathan@asite.com \\ Chris Peters \\ Asite Solutions Ltd, London; cpeters@asite.com
}

\begin{abstract}
Purpose - The purpose of this paper is to examine how contractor firms manage their relationships with extended supply chain tiers and investigate the range of ICT technologies used to facilitate such practices.

Design/methodology/approach - An on-line questionnaire survey was conducted to gather information about supply chain management operations, supplier relationship management and the ICT technologies used by contractor firms to manage their extended supply chain tiers.

Findings - The extended supply chain relationships of contractor firms are primarily composed of contractual, technical and financial entities, but findings suggest that the vision to consider extended supply chain firms when selecting suppliers are still myopic. Majority of ICT technologies are used between Tier 1 supply chain firms and there is an inconsistency in the number of technologies adopted with the extended supply chain tiers. Despite having a high involvement relationship with Tier 2 downstream firms, findings indicate a lack of use of ICT technologies to manage the organisational, personal and technological interactions with these firms.

Research limitations/implications - On the basis of different relationship types this study develops an initial framework for management of supply chains that are facilitated by relevant ICT technologies.

Originality/value - This paper provides insights into the management of extended supply chain firms by contractor firms from a relationship-centric perspective and develops an initial framework for relationship-centric supply chain management.
\end{abstract}

Keywords construction, supply chain management, ICT, relationships, contractors

Paper type Research paper

\section{Introduction}

The complex and dynamic association between firms, projects, markets and commodities makes it a very difficult task for contractor firms to manage their supply chains (Hughes et al., 2006; London, 2008). Indeed no single firm would be able to, nor would have the power and resources to, manage all the supply chain firms in a project (Holti et al., 2000). However, the firm with the biggest influence in construction projects (generally main contractors due to magnitude of their stake in the project) can exercise different levels of control to different supply chain firms in a project. Moreover, clients who have dominant position in projects usually 
appoint responsibility of supply chain management (SCM) to main contractors to better coordinate, control and/or manage project supply chains (Jones and Saad, 2003; Briscoe et al., 2004). Depending on the procurement route selected contractor firms can have huge influence as well as the resource capacity to coordinate and steer supply chains in a construction project (Smyth, 2005; Wolstenholme et al., 2009).

An optimal SCM strategy is said to be one which is extended to include firms in many layers down or up in the supply chain tiers (Jones and Saad, 2003). However, in construction industry many studies report that contractors dominantly focus on demand side of supply chains and spend too little time and effort to understand suppliers who are located in downstream tiers (Akintoye et al, 2000). As there is a growing trend to incorporate the whole-life-value, innovation, sustainability, and supply chain risk reduction concepts into extended supply chains contractors are becoming increasingly dependent on their downstream supply chains too (Cheng and $\mathrm{Li}, 2001$ ). In addition to this the push by UK government to cascade the good practices to tiers down in the supply chain is also considered to be a catalyst for management of extended supply chain tiers.

As a result of these factors there is a growing demand for traceability and openness by construction contractors to monitor, control, coordinate, and manage the extended supply chains. However, management of extended supply chain actors by contractor firms do not usually go beyond Tier 1 suppliers (that is immediate subcontractors or suppliers to contractors) as very few suppliers own all the activities along the chain (Vrijhoef and Koskela, 2000; Humphreys et al., 2003; Briscoe and Dainty, 2005; Bemelmans et al., 2012a, b). Further to this many supply firms in the industry refrain from being transparent and open about their supply chains (Briscoe and Dainty, 2005). Strategically, commercial confidentiality is believed to be one of the main factors that result in companies keeping their cards close to their chest. Exacerbated by the structural formation of construction supply chains, the inability to leverage supply market and complexity of the products are also recognised as some of the main barriers to reaching down to firms in the extended supply tiers (Cheng and Li, 2001; Lambert and Pohlen, 2001; Briscoe and Dainty, 2005). Thus it is believed that contractors have little, if none at all, awareness and knowledge about firms who are located remotely at many layers down/up in the supply chains.

The purpose of this paper is to shed light onto contractor firms' supply chain practices from a relationship-centric perspective and examine how construction contractors in the UK manage their upstream and downstream supply chain firms in extended tiers. It aims to reflect on the relationship management approaches and provide insights into the use of ICT technologies that directly or indirectly facilitate such practices. In construction specific literature there is dearth of research on the use of ICT technologies for extended supply chain interactions and inter-firm relationships. ICT technologies support a wide range of needs in supply chain interaction processes, including automation of a task, facilitation of collaboration process, and the enabling the communication of information (Benton and McHenry, 2010; Hadaya and Pellerin, 2010). However there is a lack of research into the adoption of these technologies to manage inter-firm relationships with extended supply chain tiers (Hadaya and Pellerin, 2010). It is argued that through an understanding of inter-firm relationships ICT technologies can better facilitate cooperative, collaborative and non-adversarial supply chain interactions between contractor firms and their extended supply chains.

This paper is structured in the following order. It begins with the definition of main relationship types that exist in construction supply chains and review of the use of ICT technologies for strategic and operational SCM. Research methodology is explained in the section thereafter, followed by discussion and analysis of research results. The study goes on to suggest a relationship-centric SCM framework supported with appropriate ICT technologies and concludes with a summary of the paper.

\section{Construction Supply Chain Relationships and ICT Technologies in Relationship-centric CSCM}

There are at least three types of supply chains associated with construction projects; (i) temporary supply chains, (ii) framework-specific supply chains and (iii) company strategic supply chains (permanent supply chains) (Dubois and Gadde, 2000; Bankvall et al., 2010). Vrijhoef and Koskela (2000) argued that construction specific SCM (cSCM) is about management of inter and intra-firm interactions with these supply chains in a construction project and suggested a cSCM framework that is concerned with (i) the interface between the supply chain and construction site; (ii) reducing costs related to logistics, lead-time and inventory on specific project supply chains; (iii) transferring activities from the site to earlier stages of the supply chain; and, (iv) integrated management of the supply chain with emphasis on improvement of supply chain and the site production. This approach provides a good plan for development of operational cSCM however it needs to be applied in the right context as argued by Cox and Ireland (2002). A cSCM also has a strategic organisational dimension for extended supply chain tiers. Here we follow Cox et al., 
(2006) who describe different types of engagement in construction supply chains and the strategic management approach for each (e.g.: supplier selection, supply chain sourcing, supplier development and supply chain management strategies) in dyadic and extended supply chain interactions.

A way to manage construction supply chains is through a relationship-centric perspective where the aim is to maintain an effective operational and strategic engagement with suppliers. This study defines Supplier Relationship Management (SRM) in a broader context as one of the components of SCM which is a companywide business strategy to manage its interconnected, dynamic and multi-dimensional interactions through its various interfaces so that it facilitates development of better relationships with its suppliers. In this paper the term suppliers and subcontractors are used interchangeably and refer to any firm which provide materials and/or specialist service for a contractor firm in a construction project.

cSCM that is based on relationships is an important area which is not fully explored in the literature (Meng, 2012). An earlier study by the authors indicates there is a lack of definition of different relationship types in the literature (Pala et al., 2012b). The relational cSCM is recognised as important for several reasons. First, there are many different types of relationships in an organisation's supply network and not every relationship type is appropriate for different contexts (Spekman et al., 1998; Cox and Townsend, 1998; Cox and Ireland, 2002; Ford et al., 2003). Without a clear record of with whom a business interacts and what the attributes of that relationship are, any business and operations strategy will fail to deliver the aspired benefits and develop longer-term relationships. As a result it is advocated that $\mathrm{CSCM}$ must be unique for each relationship (Briscoe and Dainty, 2005). Secondly, value in every relationship differs from one another as some relationships are considered to be more valuable than others (Ford and McDowell, 1999). For instance Spekman et al., (1998) suggested that relationship management should be distinct for every supplier. This is supported by Holti et al., (2000) who argued that it is not possible to manage all suppliers in a construction project. Hence a relationship based approach which puts appropriate emphasis on the links, values and associations in inter-firm relationships is regarded as an important facet for alignment of multiple-temporary organisations in construction projects. Lastly, certain strategic decisions can have different level of impact on some relationships (Ford and McDowell, 1999) therefore with a relationship based approach firms are able to apply correct sets of tools, processes, procedures and motives for an agile, efficient and smooth interaction.
Although the mainstream relationship research on construction supply chains is about purchasing and procurement relationships, there exits different relationship variables in an organisation's supply network in terms of value, strategic importance, complexity and other relational entities (Spekman et al., 1998; Cox and Townsend, 1998; Cox and Ireland, 2002; Meng, 2012). The relationship attributes that describe the interaction between two firms is generally conducted in relationship marketing and business management research. For example Gummesson (2008) described relationships from 30 different perspectives. Hakansson and Snehota (1995) list four variables for describing inter-firm relationships: continuity, complexity, symmetry and informality, whilst Harland (1994) and Croom et al., (2000) point to the various attributes that influence the type relationships formed. Similarly, Holmlund and Törnroos (1997) describe four factors that shape the type, form, length and intensity of relationships: mutuality, duration, process nature, and context dependence. In construction research Smyth and Edkins (2007) classify the entities of inter-firm relationships into two groups: soft attributes such as social, psychological and, personality and cultural dynamics of relationships and hard attributes such as technical, contractual and financial elements. For example as have been revealed by Lau and Rowlinson, (2009) and Laan et al., (2011) the trust attribute of supply chain relationships is recognised to be one of the most important factors that give shape and form to construction supply chain relationships.

The framework that describe relationships in construction projects are based on a previous study by the authors (Pala et al., 2012b). The four relationship types commonly cited in the literature are transactional, series of transaction, project collaboration and LongTerm Strategic Partnering relationships (Pala et al., 2012b). These relationships are characterised by seventeen attributes found in the literature and shown in Appendix 1. Transactional relationships- which are the most common type of relationship that a firm has with its suppliers- are short, simple, once-off and price-based transactional interactions between dyadic actors in the chain (Thompson et al., 1998). The series of transaction relationship usually occurs between a client who is a regular buyer or a contractor who interacts with a supplier more intensely and frequently (Cox et al., 2006). For example, most clients and contractors nowadays have a framework agreement with their preselected suppliers. Project collaboration relationships are project-based close relational arrangements between firms. Project collaboration may have been evolved from the previous relationship levels (series of transactions or transactional relationships over a period of time) or a firm may decide to work collaboratively 


\begin{tabular}{|c|c|c|}
\hline $\begin{array}{l}\text { Transactional } \\
\text { Relationships }\end{array}$ & \begin{tabular}{l}
\multicolumn{1}{c}{ Advantages } \\
- Low involvement, simple, price-based \\
transactions, \\
- Requires very little or no investment, \\
- Less risk involved, \\
- Better localised adaptations to change, \\
- Buyers can benefit from wider access to \\
knowledge, \\
- Can be a buffering mechanism against \\
unfavourable conditions (during uncertainty \\
and risky conditions) \\
- More options for variety, \\
- No commitment.
\end{tabular} & $\begin{array}{l}\text { Disadvantages } \\
\text { - Knowledge and experience does not get transferred } \\
\text { to next transaction/project hence a new learning } \\
\text { curve is climbed at every interaction, } \\
\text { - Lack of trust between parties, } \\
\text { - } \text { Adversarial terms and conditions in contracts, } \\
\text { - Hampers development of both, temporary and } \\
\text { permanent network of relationships, } \\
\text { - Limited relational interaction between firms, } \\
\text { - Higher transaction costs, } \\
\text { - Selection of suppliers based on price only, } \\
\text { - Lack of commitment; misaligned values, visions, } \\
\text { goals and objectives. }\end{array}$ \\
\hline $\begin{array}{c}\text { Series of } \\
\text { Transactions }\end{array}$ & $\begin{array}{l}\text { Existing/previous relationship is maintained, } \\
\text { Opportunities for more cooperation and } \\
\text { collaboration, } \\
\text { Performance-based relationship can easily } \\
\text { develop to a more intense interaction. }\end{array}$ & 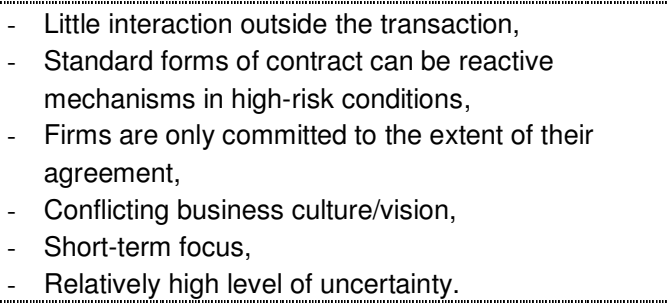 \\
\hline $\begin{array}{r}\text { Project } \\
\text { Collaboration }\end{array}$ & $\begin{array}{l}\text { Cooperative and collaborative arrangements } \\
\text { between firms, } \\
\text { - } \\
\text { Early involvement in projects, } \\
\text { - } \\
\text { Sharing of risk/benefits, } \\
\text { Mutual understanding of the vision, mission, } \\
\text { and clients requirements, } \\
\text { - Level of risk is contained to current/existing } \\
\text { project(s). } \\
\text { - Low level of uncertainty. }\end{array}$ & $\begin{array}{l}\text { New ways/methods of working can cause conflict } \\
\text { between individuals, teams and firms, } \\
\text { - There may be high power asymmetry between the } \\
\text { two firms resulting in win-lose transaction, } \\
\text { - It may not be appropriate for certain market and } \\
\text { project conditions, } \\
\text { - Requires senior level support/commitment and } \\
\text { operational level integration. }\end{array}$ \\
\hline $\begin{array}{c}\text { Long-term } \\
\text { Strategic } \\
\text { Partnering }\end{array}$ & $\begin{array}{l}\text { Integrated project delivery, } \\
\text { - Joint conflict resolution, } \\
\text { - } \text { Competitive advantage, } \\
\text { - Savings on transaction costs, } \\
\text { - Savings from improved performance and } \\
\text { efficiencies, } \\
\text { - } \text { Mutual commitment and organisational } \\
\text { alignment, } \\
\text { - Innovation and value creation, } \\
\text { - Increased client satisfaction, } \\
\text { - } \quad \text { Faster response to market/project needs, } \\
\text { - } \text { Continuous development. }\end{array}$ & $\begin{array}{l}\text { Very difficult to integrate with a supplier unless the } \\
\text { commercial gains achieved from collaboration is } \\
\text { profitable for both firms, } \\
\text { - Requires large amount of investment, commitment, } \\
\text { and resources in the relationship, } \\
\text { - High level of interdependency can cause locked-in } \\
\text { relationships. }\end{array}$ \\
\hline
\end{tabular}

with a supplier in a specific project for strategic purposes (Gadde and Dubois, 2010). The Long-term Strategic Partnerships (LTSP) are high level, strategic and long-term orientated relationships between two actors in the supply chains (Gadde and Dubois, 2010). Each of the above relationship type has advantages and disadvantages. Given the multi-level, multi-faceted and dynamic nature of any inter-firm relationships the advantages and disadvantages of these relationships are summarised in Table 1.

The four relationship categories can appear at various levels depending on the size, type and structure of the firms and projects (Dubois and Gadde, 2000; Male, 2003). In broad terms firm-firm relationships can form and develop as a result of direct or indirect encounters (Stuckenbruck, 1997). From a general project management perspective Wren (1967) described the points of interaction or 'meeting points' as interfaces. The activities occurring at each project interface can be between organisational units, disciplines and people, and systems such as technological and physical (e.g.: on-site activities) interactions (Stuckenbruck, 1997). With regards to the former interface, Bemelmans et al., (2012b) described 
the inter-firm relationships at four levels. Bemelmans et al., (2012b) stated that firms come to contact with each other during purchasing and procurement process to create relationships at project level, regional level, division level and corporate level. Here it must be noted that the interface and the level at which a relationship is conducted can be different on each project but in terms of the actors involved in the relationship Alshawi and Ingirige (2003) stated that highest interaction occurs between middle-level managers known as 'knowledge workers'.

In relation to the technological and physical interfaces ICT technologies are recognised as crucial to coordination and integration of supply chains (Hadaya and Pellerin, 2010). The core function of ICT in each of the above relationships is to support wide range of needs ranging from automation of a task and facilitation of a collaboration process to enabling of inter-firm and intra-firm communication of information between individuals (Alshawi and Ingirige, 2003; Gohil et al., 2009; Benton and McHenry, 2010). Despite the fact that communication is the key to effective project delivery majority of supply chain firms do not consistently share accurate, up-to-date, timely and reliable information with each other or with the other parties involved in the project (unless it's expressed as an obligatory condition in the contract) (Humphreys et al., 2003; Briscoe and Dainty, 2005; Titus and Bröchner, 2005). The consequent outcome of such knowledge and information deficiency is the key reason for conflicts between supply chain firms, poor quality, mistrust, delay, re-work and client dissatisfaction (Briscoe and Dainty, 2005).

There are various factors that effect a firm's decision to adopt and deploy ICT technologies (Anumba and Ruikar, 2008) however as demonstrated by Hadaya and Pellerin (2010) characteristics of the supply chain relationships (dependency, bargaining power, collaboration, and relationship length) are the main determinants of ICT adoption for different interaction needs at each interface (organisational, individual and physical). As have been argued by Dubois and Gadde (2000) and Bankvall et al., (2010) different supply chains exist in a project so each relationship that a contractor firm has with a supplier will exhibit different characteristics. Therefore in terms of its ICT requirements the four relationship types will require distinctive technological resources for management of supply chain firms. For example as relationships progress towards LTSP the characteristics of each relationship type increase in terms of longevity, volume, complexity, integration and strategic importance. In other words as relationships gain more dimensions in terms of activities, actors and resources, the magnitude of the ICT-based relationship management required to embrace these dimensions also increase (Håkansson and Snehota, 1995; Cheng, 2009).

Although there are different ICT technologies available to enable transaction, information exchange and collaboration between firms (such as Electronic Data Interchange, Project Extranets and Enterprise Resource Planning Systems) (Anumba and Ruikar, 2008; Cheng, 2009; Hadaya and Pellerin, 2010) there is scarcity of empirical research that examines contractor firms' use of any particular ICT facilitated relationship management technologies to provide them with assistance during and after the supplier selection process. What is most intensely talked about and used are web-based inter-firm collaboration technologies which are beginning to encapsulate different forms of interaction (such as tendering, procurement, design, project planning, and project management) within a common collaboration platform (Anumba and Ruikar, 2008). For example Hadaya and Pellerin (2010) argued that the main function of inter-firm ICT technologies is to support transactional and collaborative interorganisational processes, such as exchange technical documents and drawings, and share inventory information between a construction company and its key suppliers.

The interface(s) where two firms interact in a project vary from project to project however the most project relationships form at the procurement stage of a building process. This is because procurement methods and contracts are one of the earliest stages in a project and it is the first interaction that contractor firms have with their suppliers (Briscoe and Dainty, 2005). Hence procurement, purchasing, and contract management are the dominant approaches to manage inter-firm relationships in the construction industry (Khalfan et al., 2001). However to implement a comprehensive SCM requires all the other interfaces during the subsequent phases of the relationship to be managed too. Managing all the entities of a relationship in turn requires a cross-functional, dynamic and long-term orientated approach (Lambert and Cooper, 2000; London, 2008).

The methods used by contractor firms to manage supply chain relationships during procurement stage (or during purchasing and procurement of materials or services which is at any point in a project lifecycle) are generally supplementary to supplier selection strategies. At the operational level contractor firms base their supplier relationship management on their supplier selection, evaluation and negotiation strategies (Kumaraswamy et al., 2000; Cox et al., 2006) where pre-qualification metrics (e.g.: PQQ: Pre-Qualification Questionnaires), KPIs and other supplier performance measurement criteria are used to shortlist and manage supply chain firms. These mechanisms are mostly adopted in transactional, framework and project-based 
collaborative relationships and they are mostly concerned with cost and time performance analysis of suppliers (Millett and Dainty 2000; Cox et al., 2006). During the latter stages of a project, contractors make use of ICT technologies such as logistical and inventory management systems, cost accounting systems and customer/supplier relationship management systems to assess performance of suppliers but these system are generally executed in an intra-firm setting and their use in relationship management prior to forming of a relationship is not well known (Benton and McHenry, 2010). This is probably attributed to the fact that majority of these tools are used as a reactive rather than proactive mechanism to SRM.

At the strategic (organisational) level supply chain relationships are conducted in the form of project collaboration and LTSP relationships (London, 2008). Senior level professionals who are usually regional, divisional or company directors generally employ informal (or inter-personal) approaches to manage their inter-firm relationships. However high-level managers would also be concerned with strategic aspects of purchasing, logistics, materials management and construction activities of projects, hence ICT technologies such as decision support systems and knowledge management systems appear to be most relevant technologies for this level (Benton and McHenry, 2010). Nevertheless, their use in management of inter-firm supply chain relationships is not evident in research or practice.

In summary, cSCM must take into account the form of relationship that exists between supply chain firms. The transient, independent and multi-organisational characteristics of construction projects and supply chain firms require development, maintenance, and alignment of relationships in a much faster way. Due to their dynamic, multiple interface, multi-level and multiproject nature construction supply chain relationships are not easy to investigate let alone manage. Relationships-centric SCM is important but the role of ICT in facilitating better relationships requires equally important attention. While there is lack of information on the methods and tools adopted to manage inter-firm relationships in ex-post procurement stage, extensive research is conducted on inter-firm relationships which concern purchasing and procurement interactions. By utilising a relationship-centric approach this study will investigate the ICT supported SRM practices of contractor firms for dyadic and extended supply chain interactions.

\section{Research Methodology}

The research methodology was developed with the purpose of identifying ICT facilitated relationship management technologies which are currently being employed by contractor firms to manage their dyadic and extended network of relationships. The study explores the concept of cSCM from a relationshipcentric perspective. The framework which describes inter-firm relationships in construction supply chains are defined in an earlier study by the authors (Pala et al., 2012b). Appendix 1 shows that each of these relationship types exhibit different characteristics in terms of longevity, volume, complexity, integration and strategic importance for contractor firms. The study argues that each of the above-mentioned relationship types will require different ICT resources to manage, control and coordinate the dyadic and extended network of interactions.

The aim of this paper is to report on how contractor firms form relationships with their downstream suppliers, and the systems, technologies and processes they employ to manage their dyadic and extended supply chain relationships. Based on the findings of this survey the study goes on to suggest a framework on deployment of ICT technologies in relationship-centric cSCM.

\subsection{Questionnaire Design}

Questionnaire design followed a two-stage process which was also carried out in a similar study by Hadaya and Pellerin (2010). An on-line questionnaire survey was developed to capture information about contractor firms' procurement and supplier relationship management practices and the use of ICT technologies with their supply chain firms. Following the suggestions of Thietart (2001) a pilot study was conducted to increase the reliability and validity of the data collection instrument. The profile of respondents for pilot study was Procurement, Commercial Business Development and Project Managers who are representative of the target audience of this survey due to their high involvement in supply chain activities (Alshawi and Ingirige, 2003). Four interviews were conducted where participants were asked to comment and discuss the design, structure and, language and relevance of the questionnaire to their role. The feedback of interviewees was combined in a matrix table to reflect a non-biased analysis and refinement of the questionnaire. Final version of the questionnaire consists of four sections: (i) general questions, (ii) role and involvement, (iii) procurement practices, and (iv) relationship management. Multiple data collection techniques were adopted in the questionnaire design. Alongside some closed-ended questions the questionnaire design made use of 'Likert Scale' type questions to explore the perceptions of participants. There are also several questions which require respondents to rank the answers provided in the survey 
as well as 'open-ended' questions to develop a deeper understanding of the context.

\subsection{Sampling Procedure}

The profile of respondents selected for the sample population are Procurement Managers, Supply Chain Managers, Commercial Directors, Business Development Managers, Project Managers and Construction Managers who are working for UK contractor firms. The rationale behind selecting these groups of respondents was to allow breadth in answers given and capture a complete representation of the strategic and operational aspects of $\mathrm{cSCM}$ and relationship management at various project phases (design, procurement, construction and facilities management). These professions are usually involved with different aspects of cSCM and SRM so the data collected allows a comprehensive review of inter-firm relationships at multiple levels and interfaces (Alshawi and Ingirige, 2003).

Respondents were invited to participate in the survey by telephoning them, followed by personalised emails which had information about the research and how to participate in the survey. Initially around 50 telephone calls were made to contractor firms and individuals in order to pre-screen the companies to identify key informants who were engaged with interfirm activities. However due to low response rate from the original group the survey was distributed to a further 115 people whose details were obtained from search engines, professional networking sites and company websites. The whole data collection process was confined to 4 weeks and at the end the overall response rate was $30 \%$ (49 responses) from a total of 165 people approached.

\section{Analysis and Discussion}

Following section will present the research findings in the format that was arranged in the questionnaire survey and discuss the significance of the results in the context introduced earlier.

\section{Figure 1 Respondents level of involvement}

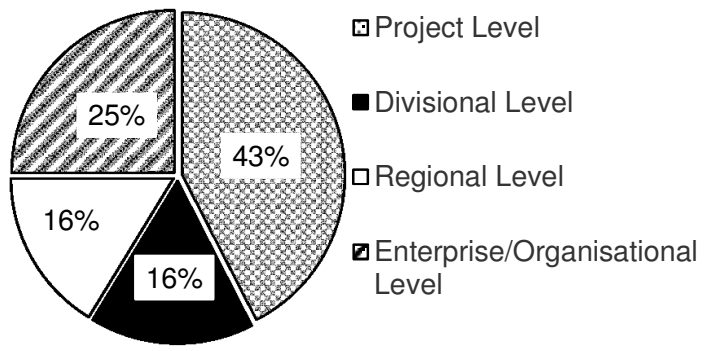

\subsection{Role and Involvement}

Survey results indicate that on average participants had 17 years of experience working in the industry. Responses were gathered from 27 different contractor firms where large contractor firms with $£ 100 \mathrm{~m}+$ turnover are dominantly represented in the survey. With regards to the role and involvement of participants Figure 1 shows that majority of respondents engage with other supply chain firms primarily at project level (19 responses) indicating that they have a direct involvement with operational aspects of supply chain management. However further analysis of the questionnaire data suggest that respondents are involved at multiple levels (17 respondents) where their job function extend beyond project based relationships to inter-firm relationships. In addition, Figure 2 confirms that survey represents responses from various interfaces where the multi-level involvement is reflected across different project phases (albeit mainly on design, procurement and construction).

Further to above over $73 \%$ of respondents indicated that they had considerable influence on inter-firm relationships whether at project, organisational or enterprise level. Insight into their role in strategic supply chain management shows that respondents relate their strategic decision making activities in the following order: (i) supplier relationship management, (ii) strategic supplier selection, (iii) supply-chain risk management, (iv) supplier development, (v) supplier coordination and (vi) client relationship management. These results suggest that the views represented in this study reflect both, operational and strategic cSCM and SRM activities of contractor firms and yield important information about inter-firm supply chain relationships

Figure 2 Respondents' level of involvement during different project phases.

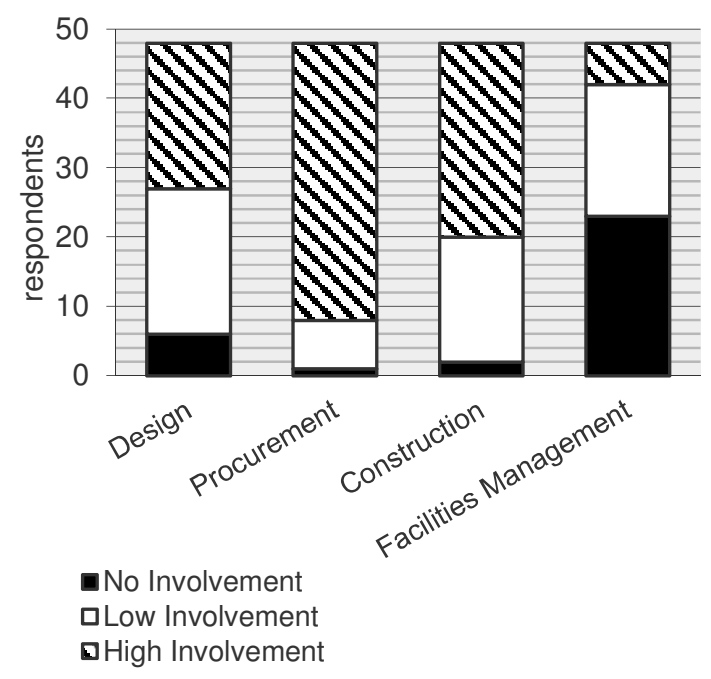


Table 2 Ranking of evaluation criteria adopted in projects

\begin{tabular}{|c|c|c|c|c|c|c|c|c|}
\hline Evaluation Criteria & Ranking: & 1 & 2 & 3 & 4 & 5 & Mean & Overall Ranking \\
\hline Previous relationship/interaction & \multirow{5}{*}{ 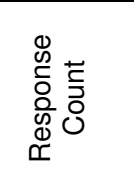 } & 9 & 17 & 9 & 8 & 4 & 2.60 & 1 \\
\hline Pre-qualification Criteria & & 18 & 8 & 4 & 7 & 10 & 2.64 & 2 \\
\hline Cheapest priced offer & & 11 & 9 & 9 & 8 & 10 & 2.94 & 3 \\
\hline Contractor's Strategic Criteria & & 5 & 8 & 15 & 8 & 11 & 3.26 & 4 \\
\hline Case-based reasoning & & 4 & 5 & 10 & 16 & 12 & 3.57 & 5 \\
\hline
\end{tabular}

at different interfaces.

\subsection{Procurement Practices}

Findings of this survey agree with the previous studies (Thompson et al., 1998) which reported that the shortterm transactional practices in supplier contract methods still persist amongst contractor firms. Respondents ranked the one-off arrangements as the most implemented procurement methods when appointing suppliers in a project. This was followed by Project Partnering/Collaboration, Framework Agreements and Long-Term Strategic Partnering relationships. It must be noted here that the adoption of transactional procurement practices should not accused of being wrong type of relationship as value gained from every relationship differs (Ford et al., 2003). This is because the context within which supply chain firms come together to 'cooperate or collaborate' cannot be intrinsic for every relationship (Cox et al., 2006). For example, in addition to the problems with infrequent and geographically fragmented projects, Akintoye et al., (2000) and, Akintoye and Main (2007) reported that main barriers to the implementation of collaborative relationships by contractor firms are largely related to the factors such as lack of market opportunity, risk sharing, trust, organisational structure, need for resource efficiency and client requirement. Therefore what needs probing is whether a particular firm is the best candidate for specific type of relationship (either Transactional, Series of Transactions, Project Partnering or LTSP relationship) and how to develop the one-off/transactional relationships which has a longterm prospect into much more cooperative and collaborative relationships.

The survey explored the relationship attributes which respondents deemed critical for any supply chain relationship. Complementing the arguments of Jones and Saad (2003), Lau and Rowlinson (2009) and Laan et al., (2011) that the trust component of relationships is a sine qua non of any business transaction; the trust, attitude and culture of the supplier firm along with their previous performance in terms of price, quality and time are the most significant factors considered by the respondents (42 and 43 responses consecutively). Relatively less emphasis was placed on the interpersonal connections, ties and networks on inter-firm relationships (20 responses) and commonalities between the firms (14 responses). Thus supplier selection strategy that is based on qualitative aspects of the tender submission rather than cheapest price alone seems to be the most important aspect of relationship initiation process. Equally important it indicates the need to focus on qualitative entities of inter-firm relationships in relationship-centric cSCM.

Table 2 shows the ranking of the evaluation criteria that are adopted by contractors to assess their suppliers. According to this Previous Relationship/Interaction has a huge influence in procurement decisions of contractor firms. A history of relationship/interaction increases the suppliers' credibility and reputation, and become a reference for future transaction. Previous relationships are an important aspect for continuity in the relationship so management of relationships should be utmost concern for better functioning of post-project operations and inter-firm relationships. On the other hand a prequalification criterion is normally the first interface in a procurement process and it is a set of minimum requirements or standards (such as financial track record, technical resources, health and safety record, relevant experience and so on) that all supply chain firms have to meet before being accepted to submit their tender and bids. It is used as a means to check the compatibility of the supplier firm with the contractor firm; hence findings support the view that prequalification criteria should be configured to reflect the unique entities of the relationship.

\subsection{Contractor Practices for Managing Extended Supply Chain Tiers}

Literature reviewed warns that realisation of better supply chain performance cannot be achieved by dyadic interactions alone (Jones and Saad, 2003). Akin to unregulated processes in construction supply chains, the lack of traceability of materials and commodities, transparency and openness prevent the opportunities for improving problems associated with 'muda' in extended supply chains. Rather than individual companies working in isolation to add value to the product/service supply chains are now increasingly becoming required to add value from the earliest stages in supply chains (Vrijhoef and Koskela, 2000). Within the construction context, for example, sustainable sourcing, whole-life- 
value, innovation and supply chain risk reduction are some of the core requirements that push the need for integrated supply chains (Akintoye et al., 2003; Briscoe and Dainty, 2005). However, in line with the earlier reports of Bemelmans et al., (2012b), Vrijhoef and Koskela (2000), Akintoye et al., (2000; 2003; 2007), findings suggest that contractor firms' vision to consider extended supply chain firms when selecting suppliers is still myopic. From the responses given about half of respondents indicated that 'few' aspects of their supplier selection strategies considered supply chains beyond their immediate tier and other half of the respondents indicated 'many' or 'most' aspects of their selection strategy was extended to other tiers below the supply chain. The polarisation of responses reflects the degree of collaboration and disintegration that exist within and between supply chain firms where both groups of respondents are equally represented in this survey.

The problem with controlling and coordinating extended supply chains is especially 'problematic' as construction projects are often formed of temporary multi-organisations (Gadde and Dubois, 2010). It was noted earlier that few contractors manage and coordinate their interaction activities along the supply chain let alone become integrated with their upstream and downstream supply chains tiers. However, the survey findings reveal that the last tier of firms which contractors have a high involvement relationship with are the Tier 2 of the downstream supply chain firms such as 'Suppliers to Subcontractors' (20 responses out of 45). This was followed by Tier 4- Raw Materials Suppliers (11 responses), Tier 3- OEMs and Suppliers' Suppliers (8 responses), and Tier 1- Specialist Subcontractors/Suppliers (6 responses). As can be seen by Figure 3 majority of inter-firm relationships are composed of contractual and technical entities. Financial and inter-personal relationships were found to be less common (except with Tier 2 firms) indicating a weaker engagement in terms of monetary and social links.

These findings suggest that contractors are beginning to stretch their relationships to firms in extended tiers primarily on a contractual and technical basis (mostly with Tier 2 firms). As the length of interaction stretches to extended tiers, findings point out to the need for identification of commercial mechanisms (such as continuity of work, incentives and open-book accounting) and technical interfaces with immediate suppliers to facilitate and diffuse transparency in contractual, technical and financial relationship layers. By managing the interfaces at each of these layers cSCM can be implemented with a more precise plan. The results with regards to the Tier 4 firms are an important indication which suggests that some contractor firms have an intense interaction with firms deep in supply chain tiers. However there could be a possible misinterpretation of this data by the respondents resulting in over representation of Tier 4 firms. This is due to the fact that some construction contractors regard their Raw Materials Suppliers, for material items such as aggregates, as their immediate (Tier 1) suppliers rather than an extended supplier in a chain of production.

The survey also attempted to understand the reasons for extending the relationships with downstream supply chain firms. In conjunction with earlier findings, survey results suggest that contractors use their financial, technical and contractual relationship to engage with extended supply chain firms to; add value to the product/service; reduce any risk involved in the supply chain; reduce the costs associated with the supply chains as well as to increase efficiencies. All of these reasons indicate a project-focused supply chain interaction with extended supply tiers. However, in addition to these results respondents also indicated external reasons such as; technical requirement, increasing client satisfaction, strategic importance of the commodity of product/service, innovation requirement, size of the package/tender; and, maximising profits as their main reason to engage with extended supply chain firms.

Findings with regards to contractor firms' relationships with their upstream supply chain firms are shown in Figure 4. The extent of relationship with upstream firms is generally confined to Tier 1 firms (20 responses out of 45) where most of these relationships are made up of financial, technical, contractual and inter-personal entities. Rest of the respondents stated that their relationships extend to Tier 2 firms (such as Project Financiers and Local Authorities) (12 responses), Tier 3 firms (such as tenants, end-users and owners) (13 responses) as a result of direct or extended contractual links. These results are in line with the earlier findings of Akintoye et al., (2000; 2003; 2007) and Briscoe and Dainty (2005) which concluded that contractor firms largely focus on their relationships with their immediate upstream firms.

Survey results also reveal that there are generally two approaches to SRM by contractor firms. Out of 48 respondents who filled this section 22 of them have indicated that SRM is left to senior level managers within their organisation. Around same number of respondents (20 responses) expressed that they used collaborative and cooperative relationship management procedures, processes and protocols (such as the BS11000 which is the British Standard for collaborative working), or their own company-specific relationship management procedures. Several respondents noted that the SRM practices are embedded into their interfirm interaction processes however the discontinuity in relationships, regular changes in relationship 
management processes and the set standards for forming relationships in public projects were cited as the main reason for lack of SRM execution within their organisation. For example several respondents echoed public procurement policies and regulations (which requires selection of firms based on compulsory competitive tendering procedure) and the EU directives (which state that procurement of materials and services above a certain threshold are subject to 2004/18/EC legislation and must go through the OJEU website) as the main reason for lack of implementation of relationship management in public projects.

\subsection{ICT Technologies in Supply Chain Interactions}

Table 3 shows the use of ICT technologies by contractor firms to facilitate cSCM with their upstream and downstream firms. According to this the most used ICT technologies with extended supply chain firms are Building Information Modelling technologies, Project Extranets (both 64 instances for all supply chain tiers), and Electronic Data Interchange Systems (62 instances). The variances, in terms of core functionality of these technologies, suggest that contractors adopt different kinds of technologies to facilitate different types of relationships they maintain with their upstream and downstream supply chains.

Although it is interesting to see BIM utilisation on top of the list (for both upstream and downstream supply chain firms) this data must be approached cautiously. Succar (2009) showed that adoption of technologies such as BIM is limited as they are being evolved and have not reached to a maturity stage. The

Figure 3 The extent of downstream supply chain relationships and relationship types

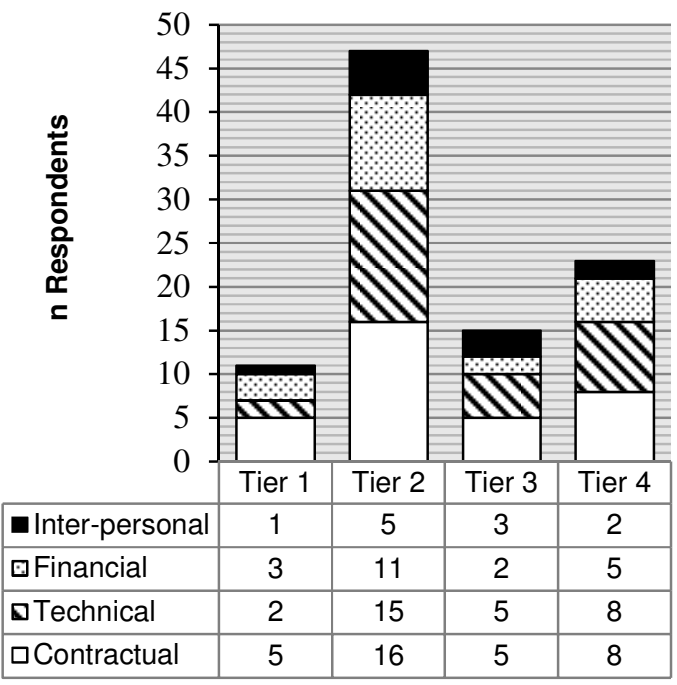

Downstream Supply Chain Tiers high response rate for use of BIM technologies can be attributed to two factors: (i) the push by UK government which is driving the momentum to get supply chain firms on the BIM bandwagon or majority of respondents are early adopters of BIM technologies in some shape and form, (ii) BIM has become a buzzword where many studies reported the ambiguity in the BIM domain in terms of concept, the definition and the technologies. Adoption of Project Extranet technologies, Integrated Databases and Electronic Data Interchange Systems indicate that there is an increased sharing of project and commercial data with both upstream and downstream supply chain firms. Similarly advanced planning and scheduling systems also demand sharing and exchange of project data for streamlining construction processes so their use by contractor firms indicate an integrated supply chain with their upstream and downstream firms.

However further analysis of this data reveals there is a disparity in the number and usage of ICT technologies with upstream and downstream supply chain tiers. The survey results in Table 3 show that there is a large difference in the number of responses received for upstream (38 responses) and downstream supply chain tiers (28 responses). Further to this contractors use more ICT technologies with their Tier 1 upstream supply chain firms (4.93 technologies on average) than their Tier 1 downstream supply chains (3.44 technologies on average). A Chi-Squared Test was used to check if there is a statistical difference in the responses to the ICT technologies and upstream/downstream supply chain tiers. The ChiSquared test results on Table $3^{+}$confirm that with 10

Figure 4 The extent of upstream supply chain relationships and relationship types

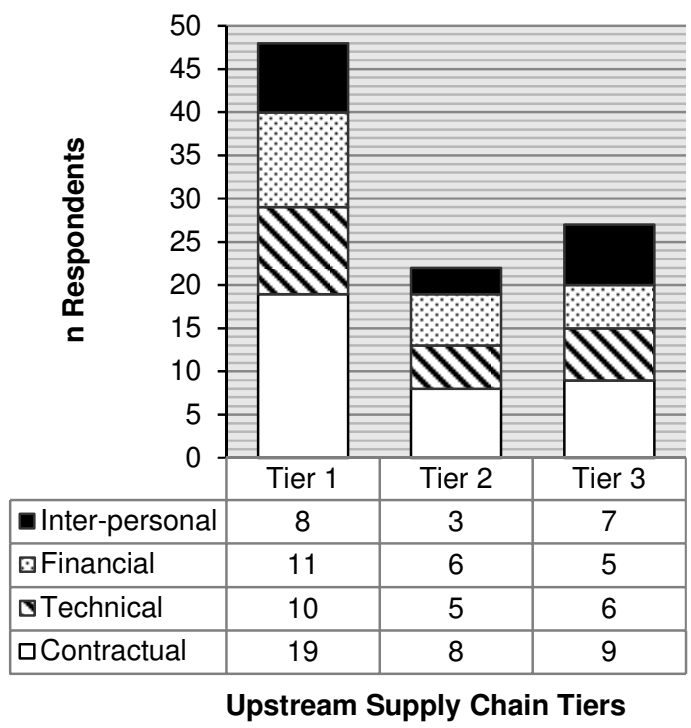


Table 3 Ranking of ICT tools/technologies used by contractors firms with the upstream and downstream supply chain firms

\begin{tabular}{|c|c|c|c|c|c|c|c|}
\hline \multirow[b]{2}{*}{ ICT Technologies that facilitate cSCM } & \multicolumn{3}{|c|}{ Upstream } & \multicolumn{4}{|c|}{ Downstream } \\
\hline & Tier 1 & Tier 2 & Tier 3 & Tier $1^{*}$ & Tier 2 & Tier 3 & Tier 4 \\
\hline Building Information Modelling & 23 & 5 & 6 & 20 & 6 & 2 & 2 \\
\hline Project Extranets & 22 & 9 & 2 & 15 & 7 & 4 & 5 \\
\hline Advanced Planning and Scheduling Systems & 20 & 9 & 1 & 14 & 6 & 5 & 3 \\
\hline Integrated Databases & 18 & 8 & 2 & 14 & 6 & 4 & 3 \\
\hline Electronic Data Interchange Systems & 23 & 7 & 2 & 13 & 9 & 4 & 4 \\
\hline Customer/Supplier Relationship Mgmt. Sys. & 23 & 4 & 4 & 13 & 7 & 2 & 5 \\
\hline Cost Accounting Systems & 16 & 11 & 3 & 13 & 7 & 3 & 5 \\
\hline Enterprise Resource Planning System & 14 & 4 & 1 & 11 & 3 & 2 & 5 \\
\hline Order Management Systems & 17 & 7 & 1 & 10 & 7 & 3 & 9 \\
\hline Logistics Management Systems & 12 & 6 & 2 & 10 & 9 & 2 & 8 \\
\hline Inventory Management Systems & 14 & 3 & 4 & 8 & 3 & 4 & 7 \\
\hline 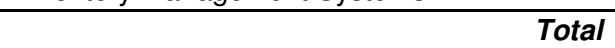 & 202 & 73 & 28 & 141 & 70 & 35 & 56 \\
\hline Number of Responses & 38 & 23 & 14 & 28 & 26 & 11 & 15 \\
\hline $\begin{array}{l}\text { Average number of ICT Technologies used by } \\
\text { all (41) respondents who filled this section: }\end{array}$ & 4.93 & 1.78 & 0.68 & 3.44 & 1.71 & 0.85 & 1.37 \\
\hline \multicolumn{8}{|c|}{${ }^{\dagger}$ Chi-Square Test Results for Tier 1 Downstream and Upstream Supply Tiers: } \\
\hline \multicolumn{8}{|c|}{ Critical Value: 18.31} \\
\hline \multicolumn{8}{|c|}{ Chi-Square Test Statistic: 2.172} \\
\hline$p$-Value: & 0.995 & & & & & & \\
\hline
\end{tabular}

degrees of freedom and $95 \%$ level of confidence $(\alpha=18.31)$ there is no relationship between the ICT technologies adopted between Tier 1 upstream and downstream supply chains (the Chi-Square value of 2.172 is smaller than critical value of 18.31 , hence the null hypothesis of independence is accepted). This is an interesting result which indicates that the influence of upstream suppliers on contractors' technology adoption with their downstream supply chains is relatively low. Findings also reveal that there is a high number of adoption of inter-organisational technologies (that is for both upstream and downstream supply chain tiers such as BIM technologies, Project Extranets, Electronic Data Interchange Systems, Advanced Planning and Scheduling Systems and Integrated Databases) for the integration of upstream and downstream supply chain tiers. Rest of the technologies utilised by contractors are intra-firm technologies which are used in-house to support their activities with their upstream and downstream suppliers.

Due to low number of instances for Tier 2 and Tier 3 supply chains (that is both upstream and downstream) a paired two-sample $t$-test was chosen to test if there is a significant difference in the number of ICT technologies adopted with firms in extended upstream/downstream supply chains. The paired twosample $t$-test was chosen as the supply chain tiers were linked with the ICT technologies. Similar to Tier 1 supply chains, the results indicate with a 95\% confidence (as indicated with a $p$ value of 0.007 ) that there is a significant difference in the number of ICT technologies adopted with extended upstream and downstream supply chain tiers. Therefore, findings of this survey suggest that despite having high involvement relationships with Tier 2 downstream firms the use of ICT technologies for interacting with tiers beyond Tier 1 firms is non-existent.

The main challenges and barriers that respondents perceived to the uptake of ICT technologies with their extended supply chains were also investigated. Recognising the financial difficulties faced in the current economic climate, 18 respondents viewed the cost aspect as the primary concern for the adoption of these technologies. Equal number of respondents reasoned the lack of awareness of these technologies to functionally extend to cover Tiers beyond their immediate supplier as another big challenge. Majority of these technologies require a mutual adoption to be implemented so without suppliers buy-in of these technologies the uptake was believed to be poor (15 responses). Another concern that was raised was the issue with compatibility and interoperability which makes it difficult to exchange information and integrate with supply chain firms (14 and 13 responses respectively).

\section{Discussion on Relationship-centric CSCM with ICT Technologies}

ICT technologies have a great potential to facilitate better cSCM between supply chain firms. Each of these technologies can support various needs of the strategic 
Figure 5 SCM approach for four categories of relationships

(a)

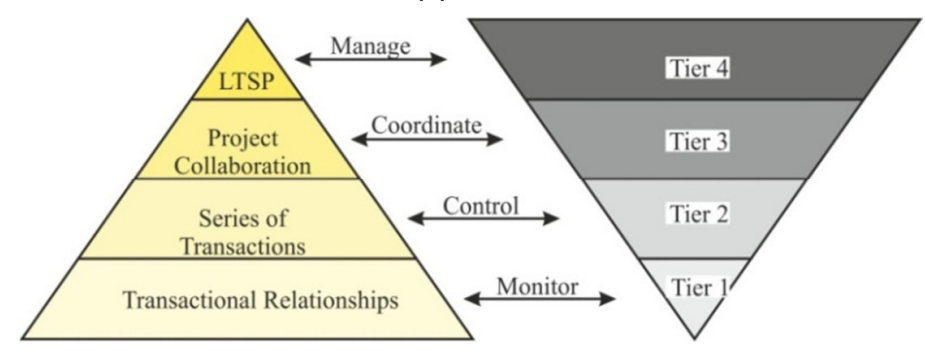

(b)

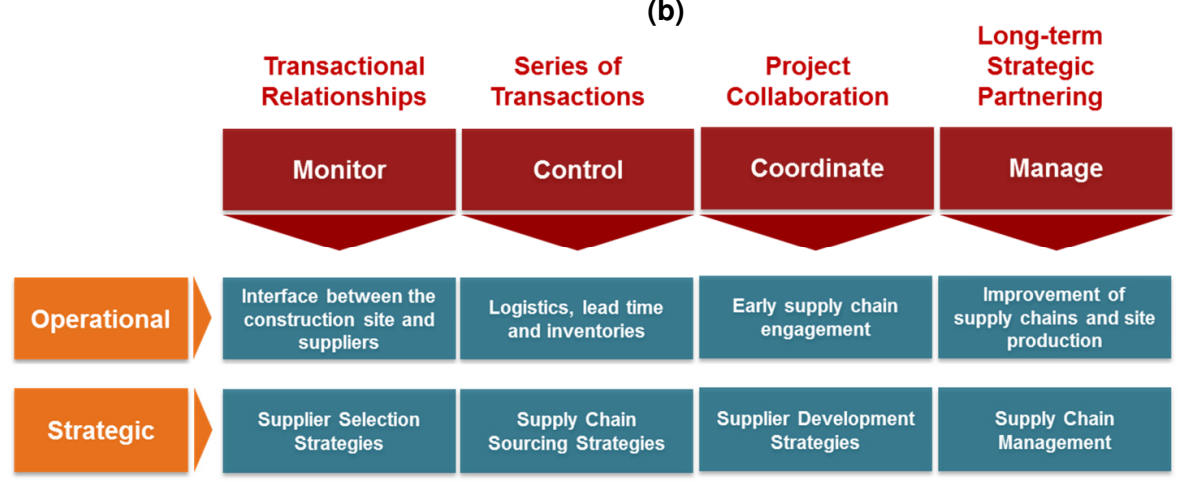

and operational aspects of cSCM. Based on four relationship categories identified earlier this study argues that cSCM should take into account the characteristics of each relationship that a contractor firm has with its suppliers as illustrated in Figure $5(a)$. Recognising the fact that every relationship requires a different management approach, the study argues that the length of supply chain interaction and management strategy for each relationship should be maintained at a comparable complexity. For example Long-term Strategic Partnering relationships which are the most intense relationship types should be managed up-to Tier 4 in the supply chain to derive all the benefits desired from the relationship such as competitive advantage, integrated project delivery, increased client satisfaction and so on. This is shown in Figure 5(b) which builds on the theoretical framework of Vrijhoef and Koskela (2000) and Cox et al., (2006) for strategic and operational cSCM. On the basis of survey results and earlier desk study it can be argued that different ICT solutions should be utilised to facilitate efficient, timely and cost-effective supply chain interactions for different relationship types.

For transactional relationships it would be suffice to monitor the interface between the construction site and Tier 1 suppliers. Monitoring would allow the core entities of a relationship - such as the supply market, type of commodity, purchase history, future portfolio expenditure and performance of supplier within the cost/time/quality criteria, to be surfaced so correct

decisions about future transactions can be made. From the strategic perspective, the process should involve monitoring contractor's own supplier selection strategies so that most appropriate firm which is capable of providing best value for the contractor firm is selected. Such selection strategies should be supported with dynamic ICT technologies that monitor suppliers' performance (in terms of price, quality and timing) and, compliance with standards and requirements set out in contractor's pre-qualification criteria.

In series of transaction relationships the aim would be to control the relationships up to Tier 2 in the supply chain. From an operational perspective the aim of the control strategy would involve an active administration procedure to reduce the costs related to logistics, leadtime and inventory. The strategic approach would be principally concerned with the supply chain sourcing strategies that take into account the extended supply chain tiers. Moreover, it would also be concerned with the workflow, procurement and electronic tendering processes with the aim of improving the flow of exchange of information, payments, billing and logistical activities between extended supply chain tiers. How much of the existing ICT technologies can support these interactions is an interesting avenue for further research but it must be recognised that ICT technologies can enable such interaction only if organisational challenges are overcome.

In project collaboration relationships, cSCM strategy would be related to getting suppliers involved 
early in the construction process. Information sharing and coordination of physical activities would be the main focus where coordinating the suppliers that are beyond Tier 3 of contractor firms would be the operational aim of cSCM. In terms of strategic cSCM, the aim would be to develop the extended supply chain firms so that performance gains can be achieved from management of extended supply chain tiers. This requires a flexible approach to $\mathrm{cSCM}$ where all firms up to Tier 3 in the supply chain is organised and coordinated in an agile fashion. Here the alignment of ICT technologies as well as systems and process along the supply chains needs to be effective and efficient to work harmoniously with each other.

The Long-term Strategic Partnering Relationships require a total relationship management approach where the supply chains extend right down to the last tier in the supply chain. Operationally, further to all of the above mentioned methods, the objective of the cSCM would be concerned with all entities attached to a relationship to gain competitive advantage, added value and reduced costs. The strategic aspect of management would involve monitoring, controlling, coordinating and managing all relational aspects of the interactions at many layers as possible such as project, organisational as well as inter-personal dimensions. It must be recognised that ICT technologies can enable such relationships only if these solutions are embraced and utilised effectively by each firm in the supply chain tier.

\section{Conclusion}

The transient, independent and multi-organisational characteristics of construction projects require development and alignment of relationships in a much faster way. Management and control of these relationships are crucially important to ensure that supply chains operate in an agile, efficient and smooth manner. Rather than looking into how to improve dyadic relationships between contractor firms and its upstream/downstream supply chain firms, this research was concerned with the management practices of contractor firms for their extended supply chain relationships.

Findings of the questionnaire survey reveal that two approaches are employed by contractor firms for relationship management: strategic management by senior level managers and specific collaborative and cooperative processes, procedures and protocols. Despite the existence of a high involvement relationship, the evidence from the study suggests that the majority of ICT technologies deployed by contractors did not extend to their Tier 2 downstream firms. These findings indicate a very limited approach to SRM by contractor firms that restrict the opportunity for a 'seamless and efficient' management of supplier relationships by taking advantage of effective and available ICT technologies. Most common ICT technologies used between contractor firms and their supply chains were Building Information Modelling technologies, Project Extranets, Electronic Document Interchange systems which were primarily used between Tier 1 upstream/downstream supply chain firms. Comparison of ICT technologies adoption between upstream and downstream supply chains revealed that there is an inconsistent adoption of technologies along the extended supply chain tiers where contractor firms' upstream relationships' have no influence on the adoption of technologies by downstream firms. In order to increase the adoption of these technologies within and between supply chain firms, as well as make their use more effective, key issues with cost, lack of awareness, suppliers' reluctance to adopt, as well as compatibility and interoperability needs to be given due consideration for the whole industry.

In terms of managing extended supply chain tiers, the questionnaire survey revealed that contractor firms' main association with supply firms in Tier 2 downstream supply chains are contractual, technical and financial. This finding points to a need for identification of commercial mechanisms and technical interfaces with immediate suppliers so that relationships can be built with extended supply chain firms. Contractual and commercial mechanisms such as continuity of work, financial incentives and open book accounting are some of the concepts that foster transparency in dyadic relationships but what is their effect on extended supply chain relationships is unknown. Similarly, for streamlined collaborative supply chain practices the technical involvement with extended supply chain firms must be supported with appropriate ICT technologies. The technical supply chain interactions and interfaces need to be investigated so that ICT technologies can be used to facilitate SRM with extended supply chains.

The review of literature and the evidence from the study reveals that SRM is a vital element of extended cSCM and ICT technologies can facilitate relationship management process if they are used consistently and effectively between supply chain firms. The theoretical framework for relationship-centric cSCM is a work in progress which involves additional development, testing and analysis. Currently such a development is being undertaken to create a cSCM framework for contractor firms who play a key role in the management and control of construction project supply chains.

\section{Acknowledgements}

The authors would like to thank the EPSRC (Engineering and Physical Sciences Research Council) 
for their support of this research and all the respondents who participated in the survey.

\section{References}

Akintoye, A., Hardcastle, C., Beck, M., Chinyio, E. and Asenova, D. (2003), "Achieving best value in private finance initiative project procurement", Construction Management and Economics, Vol. 21 No. 5, pp. 461470.

Akintoye, A. and Main, J. (2007), "Collaborative relationships in construction: the UK contractors' perception", Engineering, Construction and Architectural Management, Vol. 14 No. 6, pp. 597617.

Akintoye, A., McIntosh, G. and Fitzgerald, E. (2000), "A survey of supply chain collaboration and management in the UK construction industry", European Journal of Purchasing \& Supply Management, Vol. 6 No. 3-4, pp. 159-168.

Alshawi, M. and Ingirige, B. (2003), "Web-enabled project management: an emerging paradigm in construction," Automation in Construction, Vol. 12 No. 4, pp. 349-364.

Anumba, C.J. and Ruikar, K.D. (Eds.). (2008), eBusiness in Construction, Wiley-Blackwell.

Bankvall, L., Bygballe, L.E., Dubois, A. and Jahre, M. (2010), "Interdependence in supply chains and projects in construction", Supply Chain Management: An International Journal, Vol. 15 No. 5, pp. 385-393.

Bemelmans, J., Voordijk, H. and Vos, B. (2012a), Supplier-contractor collaboration in the construction industry. A taxonomic approach to the literature of the 2000-2009 decade", Engineering Construction and Architectural Management, Vol. 19 No. 4, pp. 1-1. Bemelmans, J., Voordijk, H., Vos, B. and Buter, J. (2012b), "Assessing Buyer-Supplier Relationship Management: Multiple Case-Study in the Dutch Construction Industry", Journal Construction Engineering and Management, Vol. 138 No. 1, pp. 163-176.

Benton, W.C.J. and McHenry, L.F. (2010), Construction Purchasing \& Supply Chain Management, London, McGraw-Hill.

Briscoe, G. and Dainty, A.R.J. (2005), "Construction supply chain integration: an elusive goal?", Supply Chain Management: An International Journal, Vol. 10 No. 4, pp. 319-326.

Briscoe, G., Dainty, A.R.J., Millett, Sarah and Neale, R. (2004), "Client-led strategies for construction supply chain improvement”, Construction Management and Economics, Vol. 22 No. 2, pp. 193-201.

Cheng, C.P. (2009), SC Collaborator: A Service Oriented Framework for Construction Supply Chain Collaboration and Monitoring, University of Stanford.

Cheng, E. and Li, H. (2001), "An e-business model to support supply chain activities in construction",
Logistics Information Management, Vol. 14 No. 1, pp. $68-77$.

Cox, A., Ireland, P. and Townsend, M. (2006), "The power and leverage perspective: an alternative view of relationship and performance management", Managing in Construction Supply Chains and Markets, London, Thomas Telford, pp. 28-47.

Cox, A. and Ireland, P. (2002), "Managing construction supply chains: the common sense approach", Engineering, Construction and Architectural Management, Vol. 9 No. 5-6, pp. 409-418.

Cox, A. and Townsend, M. (1998), Strategic Procurement in Construction. Towards better practice in the management of construction supply chains, London, Thomas Telford.

Croom, S., Romano, P. and Giannakis, M. (2000), "Supply Chain Management: An Analytical Framework for Critical Literature Review", European Journal of Purchasing \& Supply Management, Vol. 6 No. 1, pp. 67-83.

Dubois, A. and Gadde, L.-E. (2000), "Supply strategy and network effects - purchasing behaviour in the construction industry", European Journal of Purchasing \& Supply Management, Vol. 6, pp. 207215.

Ford, D., Gadde, L.-E., Håkansson, H. and Snehota, I. (2003), Managing Business Relationships, London, John Wiley and Sons, $2^{\text {nd }}$ Ed.

Ford, D. and McDowell, R. (1999), "Managing Business Relationships by Analyzing the Effects and Value of Different Actions", Industrial Marketing Management, Vol. 28 No. 5, pp. 429-442.

Gadde, L.-E. and Dubois, A. (2010), "Partnering in the construction industry-Problems and opportunities", Journal of Purchasing \& Supply Management, Vol. 16 No. 4, pp. 254-263.

Gohil, U., Carillo, P.M., Ruikar, K.D. and Anumba, C.J. (2009), "Fostering Collaboration within an SME Services Organisation", International Journal of Knowledge, Culture and Change in Organisations, Vol. 9 No. 4, pp. 107-122.

Gummesson, E. (2008), Total relationship marketing, Oxford, UK, Butterworth-Heinemann.

Hadaya, P. and Pellerin, R. (2010), "Determinants of construction companies' use of web-based interorganizational information systems", Supply Chain Management: An International Journal, Vol. 15 No. 5, pp. 371-384.

Håkansson, H. and Snehota, I. (Editors) (1995), Developing relationships in business networks, London, Routledge, $1^{\text {st }}$ ed.

Harland, C.M. (1994), Supply Chain Management: Perceptions of Requirements and Performance in European Automotive Aftermarket Supply Chains, University of Warwick. 
Holmlund, M. and Törnroos, J.-Å. (1997), "What are relationships in business networks?", Management Decision, Vol. 35 No. 4, pp. 304-309.

Holti, R., Nicolini, D. and Smalley, M. (2000), The handbook of supply chain management: The essentials, London, CIRIA Publication C546.

Hughes, W., Hillebrandt, P., Greenwood, D. and Kwawu, W. (2006), Procurement in the Construction Industry, Oxon, Taylor and Francis.

Humphreys, P., Matthews, J. and Kumaraswamy, M.M. (2003), "Pre-construction project partnering: from adversarial to collaborative relationships", Supply Chain Management: An International Journal, Vol. 8 No. 2, pp. 166-178.

Jones, M. and Saad, M. (2003), Managing Innovation in Construction, London, Thomas Telford.

Khalfan, M., Anumba, C.J., Siemieniuch, C.E. and Sinclair, M. a. (2001), "Readiness Assessment of the construction supply chain for concurrent engineering", European Journal of Purchasing \& Supply Management, Vol. 7 No. 2, pp. 141-153.

Kumaraswamy, M.M., Palaneeswaran, E. and Humphreys, P. (2000), "Selection matters in construction supply chain optimisation", International Journal of Physical Distribution \& Logistics Management, Vol. 30 No. 7/8, pp. 661-680.

Laan, A., Noorderhaven, N., Voordijk, H. and Dewulf, G. (2011), "Building trust in construction partnering projects: An exploratory case-study", Journal of Purchasing \& Supply Management, Vol. 17 No. 2, pp. 98-108.

Lambert, D.M. and Cooper, M.C. (2000), "Issues in Supply Chain Management", Industrial Marketing Management, No. 29, pp. 65-83.

Lambert, D.M. and Pohlen, T.L. (2001), "Supply Chain Metrics", The International Journal of Logistics Management, Vol. 12 No. 1, pp. 1-19.

Lau, E. and Rowlinson, S. (2009), "Interpersonal trust and interfirm trust in construction projects", Construction Management and Economics, Vol. 27 No. 6, pp. 539-554.

London, K. (2008), Construction Supply Chain Economics, Oxon, Taylor and Francis.

Male, S. (2003), "Future trends in construction procurement: procuring and managing demand supply chains in construction", in Bower, D. (Ed.), Management of Procurement, London, Thomas Telford, pp. 228-249.

Meng, X. (2012), “The effect of relationship management on project performance in construction", International Journal of Project Management, Vol. 30 No. 2, pp. 188-198.

Millett, SJ and Dainty, A. (2000), "Towards an integrated construction supply network: subcontractors perspectives", in Akintoye, A. (Ed.),
Proceedings of the 16th Annual ARCOM Conference, Glasgow, ARCOM, Vol. 2, pp. 705-714.

Pala, M., Edum-Fotwe, F, Ruikar, K.D., Peters, C. and Doughty, N. (2012a), "Achieving Effective Project Delivery Through Improved Supplier Relationship Management", in Javernick-Will,A. and Mahalingham, A. (Eds.),Working Paper Proceedings. Engineering Project Organisations Conference, Rheden, Netherlands, EPOS, pp. 1-12.

Pala, M., Edum-Fotwe, Francis, Ruikar, K.D., Peters, C. and Doughty, N. (2012b), "Improving Supplier Relationship Management within the AEC Sector", in Smith, S. (Ed.), 28th Annual ARCOM Conference, Edinburgh, ARCOM, pp. 707-717.

Smyth, H. (2005), "Procurement push and marketing pull in supply chain management: The conceptual contribution of relationship marketing as a driver in project financial performance", Journal of Financial Management of Property and Construction, Vol. 10 No. 1, pp. 33-44.

Smyth, H. and Edkins, A. (2007), "Relationship management in the management of PFI/PPP projects in the UK", International Journal of Project Management, Vol. 25 No. 3, pp. 232-240.

Spekman, R.E., Kamauff Jr, J. w. and Myhr, N. (1998), "An empirical investigation into supply chain management: a perspective on partnerships", Supply Chain Management: An International Journal, Vol. 3 No. 2, pp. 53-67.

Stuckenbruck, L.C. (1997), "Integration: The Essential Function of Project Management", in Cleland, D. and King, W.R. (Eds.), Project Management Handbook, Wiley Online Library, $2^{\text {nd }}$ Ed., pp. 207-232.

Succar, B. (2009), "Building information modelling framework: A research and delivery foundation for industry stakeholders", Automation in Construction, Vol. 18 No. 3, pp. 357-375.

Thietart, R.-A. (Ed.) (2001), Doing Management Research. A Comprehensive Guide, London, Sage Publications.

Thompson, I., Cox, A. and Anderson, L. (1998), "Contracting strategies for the project environment", European Journal of Purchasing \& Supply Management, Vol. 4 No. 1, pp. 31-41.

Titus, S. and Bröchner, J. (2005), "Managing information flow in construction supply chains", Construction Innovation: Information, Process, Management, Vol. 5 No. 2, pp. 71-82.

Vrijhoef, R. and Koskela, L. (2000), "The four roles of supply chain management in construction", European Journal of Purchasing \& Supply Management, Vol. 6 No. 3-4, pp. 169-178.

Wolstenholme, A., Egan, J., Latham, M. and Raynsford, N. (2009), Never waste a good crisis: A review of progress since Rethinking Construction and thoughts for our future, London: Constructing Excellence. 
Wren, D.A. (1967), "Interface and Interorganizational Coordination", Academy of Management Journal, Vol. 10 No. 1, pp. 69-81 
Appendix 1 Characteristics of each relationship type against relationship determinants

\begin{tabular}{|c|c|c|c|c|}
\hline $\begin{array}{l}\text { Relationship } \\
\text { Elements }\end{array}$ & $\begin{array}{l}\text { Transactional } \\
\text { Relationships }\end{array}$ & $\begin{array}{l}\text { Series of } \\
\text { Transactions }\end{array}$ & Project Collaboration & $\begin{array}{l}\text { Long-term Strategic } \\
\text { Partnership }\end{array}$ \\
\hline Continuity & $\begin{array}{l}\text { Infrequent and irregular } \\
\text { interactions and } \\
\text { transactions. } \\
\text { Transactional relationships } \\
\text { are dynamic and can lead } \\
\text { to another transaction or } \\
\text { series of transactions. }\end{array}$ & $\begin{array}{l}\text { Dimensions of interaction } \\
\text { are much more dynamic, } \\
\text { frequent and intense but } \\
\text { lack consistency and } \\
\text { regularity. }\end{array}$ & $\begin{array}{l}\text { Project based } \\
\text { relationship, i.e.: } \\
\text { interaction and } \\
\text { transaction based on } \\
\text { projects where the } \\
\text { relationship is regarded } \\
\text { as the best option for the } \\
\text { contracting firm. }\end{array}$ & $\begin{array}{l}\text { Continuous, long-term } \\
\text { relationships. Intense form } \\
\text { of relationship at every } \\
\text { project that contractor firm } \\
\text { gets. }\end{array}$ \\
\hline Complexity & $\begin{array}{l}\text { Low volume of } \\
\text { transactions, low asset } \\
\text { specificity products, } \\
\text { materials and services. } \\
\text { Generally involves } \\
\text { interaction/transaction } \\
\text { between two companies } \\
\text { (dyadic). Inter-personal } \\
\text { relationships are at } \\
\text { operational/project level. }\end{array}$ & $\begin{array}{l}\text { Volume of } \\
\text { transaction/interaction is } \\
\text { high due to benefits to be } \\
\text { gained from economies of } \\
\text { scale or strategic } \\
\text { purchasing, however } \\
\text { focus is on a particular } \\
\text { component OR single } \\
\text { element of a project. } \\
\text { Complexity therefore is } \\
\text { low (no interaction } \\
\text { between other supply } \\
\text { chain firms). Managers } \\
\text { and more senior people } \\
\text { get involved in the } \\
\text { relationship. }\end{array}$ & $\begin{array}{l}\text { High asset specificity and } \\
\text { transaction is generally at } \\
\text { project level, however } \\
\text { volume of } \\
\text { transaction/interaction } \\
\text { depends on the project's } \\
\text { properties (size, } \\
\text { complexity, design etc.) } \\
\text { Length of the supply } \\
\text { chain extends beyond } \\
\text { immediate tier of the } \\
\text { supplier/buyer. Teams of } \\
\text { people get engaged in the } \\
\text { relationship. }\end{array}$ & $\begin{array}{l}\text { Length and complexity of } \\
\text { the chain is very } \\
\text { sophisticated. Involves } \\
\text { integrated project delivery } \\
\text { which include complex and } \\
\text { high-volume } \\
\text { interaction/transaction } \\
\text { between the firms. More } \\
\text { senior level involvement in } \\
\text { decision making but } \\
\text { relationships extend beyond } \\
\text { a few individuals to cover } \\
\text { majority of the project team } \\
\text { and people who deal with, } \\
\text { for example, accounts, } \\
\text { marketing and PR. }\end{array}$ \\
\hline Symmetry & $\begin{array}{l}\text { High power asymmetry in } \\
\text { terms of human, } \\
\text { knowledge, financial and } \\
\text { technological resources } \\
\text { between firms. }\end{array}$ & $\begin{array}{l}\text { Usually high power } \\
\text { asymmetry in human, } \\
\text { knowledge, financial and } \\
\text { technological resources of } \\
\text { the firms. }\end{array}$ & $\begin{array}{l}\text { High power asymmetry } \\
\text { may be compensated by } \\
\text { one of the party's strength } \\
\text { in a particular resource. }\end{array}$ & $\begin{array}{l}\text { Low or no power asymmetry } \\
\text { between firms, however one } \\
\text { party may be able to } \\
\text { dominate or influence the } \\
\text { relationship more due to its } \\
\text { purchasing power. }\end{array}$ \\
\hline $\begin{array}{l}\text { Exchange/ } \\
\text { Interaction }\end{array}$ & $\begin{array}{l}\text { Content of the exchange } \\
\text { generally include a single } \\
\text { product/service which is } \\
\text { acquired on a one-off } \\
\text { basis. }\end{array}$ & $\begin{array}{l}\text { Relationship consists of } \\
\text { stream of transactional } \\
\text { interactions in multi- } \\
\text { projects. Content of } \\
\text { exchange may extend } \\
\text { beyond single product } \\
\text { and include series of } \\
\text { commodities. }\end{array}$ & $\begin{array}{l}\text { Content of the } \\
\text { relationship concerns } \\
\text { interactions which is at } \\
\text { project level and include } \\
\text { all the sub-components of } \\
\text { the project such as a } \\
\text { project package. }\end{array}$ & $\begin{array}{l}\text { Integrated project delivery } \\
\text { for majority of the projects } \\
\text { involved. }\end{array}$ \\
\hline $\begin{array}{l}\text { Relationship } \\
\text { Embeddedness }\end{array}$ & $\begin{array}{l}\text { Few connections, ties and } \\
\text { legal links prior to the } \\
\text { interaction. }\end{array}$ & $\begin{array}{l}\text { May have been involved } \\
\text { in a transactional } \\
\text { relationship before. } \\
\text { There are some } \\
\text { connections, ties and } \\
\text { contractual agreements } \\
\text { between the parties } \\
\text { embedded in the } \\
\text { relationship. }\end{array}$ & $\begin{array}{l}\text { May have been involved } \\
\text { in portfolio of projects and } \\
\text { have an established } \\
\text { relationship setting where } \\
\text { parties work together } \\
\text { which would have a low- } \\
\text { medium level of impact on } \\
\text { relationships with other } \\
\text { firms. }\end{array}$ & $\begin{array}{l}\text { Relationship is highly } \\
\text { embedded within both } \\
\text { parties' businesses and } \\
\text { could have serious impact } \\
\text { on other relationships. }\end{array}$ \\
\hline $\begin{array}{l}\text { Formality, } \\
\text { Informality and } \\
\text { Transparency }\end{array}$ & $\begin{array}{l}\text { Interaction is highly formal } \\
\text { and follows standardised } \\
\text { generic business } \\
\text { processes/procedures } \\
\text { (e.g.: paying and receiving } \\
\text { for the products/services). } \\
\text { No transparency in the } \\
\text { relationship (i.e.: break } \\
\text { down of costs) }\end{array}$ & $\begin{array}{l}\text { Formal procedures with } \\
\text { some configured business } \\
\text { processes and } \\
\text { procedures. } \\
\text { Transparency is limited to } \\
\text { specific interaction. }\end{array}$ & $\begin{array}{l}\text { Risk and reward sharing } \\
\text { mechanisms for individual } \\
\text { projects. Some informal } \\
\text { processes/procedures are } \\
\text { in place when completing } \\
\text { a task although majority } \\
\text { of these are between } \\
\text { senior/middle managers. }\end{array}$ & $\begin{array}{l}\text { A lot of formal and informal } \\
\text { connections between } \\
\text { different levels. } \\
\text { Processes/procedures/proto } \\
\text { cols can follow informal } \\
\text { arrangements between } \\
\text { individuals/firms. Risk and } \\
\text { reward sharing mechanisms } \\
\text { may exist in all interactions. } \\
\text { Transparent business } \\
\text { operations between inter- } \\
\text { firm relationships. }\end{array}$ \\
\hline $\begin{array}{l}\text { Attitude, Trust } \\
\text { and Commitment }\end{array}$ & $\begin{array}{l}\text { Commitment, trust and } \\
\text { attitude is irrelevant in the } \\
\text { transaction/interaction. }\end{array}$ & $\begin{array}{l}\text { Some trust exists; parties } \\
\text { are committed to the } \\
\text { extent of their } \\
\text { agreements. }\end{array}$ & $\begin{array}{l}\text { There is an established } \\
\text { project culture, high level } \\
\text { of trust and commitment } \\
\text { between the parties } \\
\text { however it is generally } \\
\text { discontinuous as same } \\
\text { project teams rarely re- } \\
\text { assemble on subsequent } \\
\text { projects }\end{array}$ & $\begin{array}{l}\text { Organisational and project } \\
\text { culture in an environment of } \\
\text { honesty, blame-free, high } \\
\text { level of inter-firm trust and } \\
\text { commitment at all levels. }\end{array}$ \\
\hline
\end{tabular}




\begin{tabular}{|c|c|c|c|c|}
\hline Market Structure & $\begin{array}{l}\text { Product/service is largely } \\
\text { available in the market and } \\
\text { there are competing firms } \\
\text { for the supply of similar } \\
\text { commodity }\end{array}$ & $\begin{array}{l}\text { Product/service is largely } \\
\text { available in the market } \\
\text { and there are competing } \\
\text { firms for the supply of } \\
\text { similar commodity }\end{array}$ & $\begin{array}{l}\text { Firms generally operating } \\
\text { in single market and/or } \\
\text { specialised in a particular } \\
\text { product/service. }\end{array}$ & $\begin{array}{l}\text { Firms generally operating in } \\
\text { single market and/or } \\
\text { specialised in a particular } \\
\text { product/service. }\end{array}$ \\
\hline Firm Position & $\begin{array}{l}\text { Can be two or three tiers } \\
\text { above/below in the supply } \\
\text { chain (relative to the focal } \\
\text { firm), however } \\
\text { transactional relationships } \\
\text { can also be next tier } \\
\text { supply chain firms which } \\
\text { are nominated by the } \\
\text { client. }\end{array}$ & $\begin{array}{l}\text { Firms which are one or } \\
\text { two tiers above/below in } \\
\text { the supply chain. }\end{array}$ & $\begin{array}{l}\text { Firms which are one tier } \\
\text { above/below in the supply } \\
\text { chain. }\end{array}$ & $\begin{array}{l}\text { Firms which are one tier } \\
\text { above/below in the supply } \\
\text { chain }\end{array}$ \\
\hline $\begin{array}{l}\text { Dependence and } \\
\text { Congruence }\end{array}$ & $\begin{array}{l}\text { No dependence and highly } \\
\text { differentiated businesses. }\end{array}$ & $\begin{array}{l}\text { Low level of dependence } \\
\text { and highly differentiated } \\
\text { businesses. }\end{array}$ & $\begin{array}{l}\text { High level of dependence } \\
\text { and some congruence } \\
\text { required in the } \\
\text { relationship. }\end{array}$ & $\begin{array}{l}\text { Interdependence and high } \\
\text { level of congruence in the } \\
\text { relationship. }\end{array}$ \\
\hline Collaboration & No collaboration. & Collaboration is rare. & $\begin{array}{l}\text { Collaboration takes place } \\
\text { on a project-by-project } \\
\text { basis. }\end{array}$ & $\begin{array}{l}\text { Collaboration is long-term } \\
\text { and involve all levels of the } \\
\text { inter-firm interaction. }\end{array}$ \\
\hline $\begin{array}{l}\text { Risk and } \\
\text { Uncertainty }\end{array}$ & $\begin{array}{l}\text { Low level of risk to buyer } \\
\text { firm. Relatively higher } \\
\text { uncertainty in the quality of } \\
\text { the product/service, } \\
\text { although much of it } \\
\text { depends on the } \\
\text { standardisation and asset } \\
\text { specificity of the } \\
\text { commodity. }\end{array}$ & $\begin{array}{l}\text { Low level of risk for the } \\
\text { buyer firm. Uncertainty is } \\
\text { low due to previously } \\
\text { established } \\
\text { transactions/interactions. }\end{array}$ & $\begin{array}{l}\text { Level of risk is contained } \\
\text { to current project only. } \\
\text { Minimum uncertainty as } \\
\text { firms has established a } \\
\text { longer-term relationship. }\end{array}$ & $\begin{array}{l}\text { Risk of relationship failing is } \\
\text { low and uncertainty is } \\
\text { minimal. }\end{array}$ \\
\hline Adaptation & $\begin{array}{l}\text { No specific adaptations } \\
\text { between the firms. }\end{array}$ & $\begin{array}{l}\text { Some adaptation between } \\
\text { the firms but limited in } \\
\text { scope and extension } \\
\text { (e.g.: temporary } \\
\text { adaptations such as code } \\
\text { of practice for business } \\
\text { transactions) }\end{array}$ & $\begin{array}{l}\text { Majority of the investment } \\
\text { by both firms are on } \\
\text { operational adaptations } \\
\text { which are at project level. }\end{array}$ & $\begin{array}{l}\text { Mutual adaptations are } \\
\text { long-term and companywide } \\
\text { (both strategic and } \\
\text { operational, e.g.: technical } \\
\text { adaptations, administrative } \\
\text { routines, knowledge-based } \\
\text { adaptations) }\end{array}$ \\
\hline Attraction & $\begin{array}{l}\text { Independent relationships } \\
\text { that involve no } \\
\text { commitment. } \\
\text { Relationships are not seen } \\
\text { important. } \\
\text { Transaction/interaction is } \\
\text { attractive primarily due to } \\
\text { cost factors. }\end{array}$ & $\begin{array}{l}\text { Firms are beginning to } \\
\text { show appreciation and } \\
\text { commitment for a more } \\
\text { frequent interaction. } \\
\text { Relationship is attractive } \\
\text { due to cost, brand image, } \\
\text { experience and other } \\
\text { factors. }\end{array}$ & $\begin{array}{l}\text { There is a commitment } \\
\text { from both firms for their } \\
\text { relationship to continue. } \\
\text { Firms are dependent on } \\
\text { each other due to shared } \\
\text { stakes in the project. }\end{array}$ & $\begin{array}{l}\text { High level of commitment } \\
\text { from both parties to } \\
\text { maintain the relationship. } \\
\text { Firms are highly dependent } \\
\text { on each other due to } \\
\text { amount of investment in the } \\
\text { relationship and strategic } \\
\text { importance. }\end{array}$ \\
\hline $\begin{array}{l}\text { Closeness and } \\
\text { Remoteness }\end{array}$ & $\begin{array}{l}\text { Weak connections } \\
\text { between firms (only } \\
\text { operational links between } \\
\text { firms) and none/very } \\
\text { limited physical contact } \\
\text { with offices. If the } \\
\text { transaction is international } \\
\text { there is probably a high } \\
\text { level of cultural and } \\
\text { organisational differences } \\
\text { between the firms }\end{array}$ & $\begin{array}{l}\text { Some strong connections } \\
\text { but these are generally at } \\
\text { the managerial level. } \\
\text { Firms are generally close } \\
\text { to each other as } \\
\text { arrangements normally } \\
\text { involve firms who are at } \\
\text { local and regional } \\
\text { proximity of the buyer } \\
\text { firm. }\end{array}$ & $\begin{array}{l}\text { Teams may share the } \\
\text { same facilities. Firms' } \\
\text { office location may be } \\
\text { distant to each other but } \\
\text { regular meetings are } \\
\text { carried out to keep close } \\
\text { contact. }\end{array}$ & $\begin{array}{l}\text { Firms have shared project } \\
\text { offices and facilities to } \\
\text { support structural and } \\
\text { functional integration. }\end{array}$ \\
\hline $\begin{array}{l}\text { Customisation, } \\
\text { Standardisation } \\
\text { and } \\
\text { Prefabrication }\end{array}$ & $\begin{array}{l}\text { No specific or } \\
\text { standardised } \\
\text { processes/procedures in } \\
\text { and between the dyadic } \\
\text { interactions. }\end{array}$ & $\begin{array}{l}\text { Some established custom } \\
\text { processes/procedures but } \\
\text { interactions are not } \\
\text { standardised. }\end{array}$ & $\begin{array}{l}\text { Standardised processes } \\
\text { are in place to complete } \\
\text { routine project tasks. }\end{array}$ & $\begin{array}{l}\text { Majority of the routine } \\
\text { tasks/processes/procedures } \\
\text { are standardised. }\end{array}$ \\
\hline $\begin{array}{l}\text { Social } \\
\text { Relationships }\end{array}$ & $\begin{array}{l}\text { No social interaction } \\
\text { between the } \\
\text { firms/individuals }\end{array}$ & $\begin{array}{l}\text { Social interactions are } \\
\text { rare and only contained } \\
\text { within senior/managerial } \\
\text { level relationships. }\end{array}$ & $\begin{array}{l}\text { Established social } \\
\text { relationships through } \\
\text { professional/social } \\
\text { network sites (e.g.: } \\
\text { Facebook, Linkedln, } \\
\text { Twitter). }\end{array}$ & $\begin{array}{l}\text { Strong social connections } \\
\text { through professional/social } \\
\text { networking sites or through } \\
\text { other social activities } \\
\text { (personal or organisational). }\end{array}$ \\
\hline
\end{tabular}

